\title{
Molecular Detection of Staphylococcal enterotoxin C (SEC) and Staphylococcal enterotoxin D (SED) from the Cattle Nares in Aizawl, Mizoram (India)
}

\author{
Lalnunfela, J. Lalmuanpuia*, E. Motina, D. Deka and G. J. Lallawmkimi \\ Department of Veterinary Public Health and Epidemiology, C.V.Sc \& A.H., \\ Selesih, Aizawl, Mizoram - 796014, India \\ *Corresponding author
}

\section{A B S T R A C T}

Keywords

Staphylococcal

enterotoxins,

livestock animals,

nasal swabs of goat

Article Info

Accepted:

10 January 2021

Available Online:

10 February 2021
Staphylococcus aureus is a gram-positive bacteria commonly found on the skin or mucous membranes of both humans and animals. The bacterium is an opportunistic pathogen that can lead to many human and animal diseases that are self-limiting and even life-threatening. Symptoms such as rapid onset of nausea, vomiting, stomach cramps and diarrhoea are part of staphylococcal food poisoning. The bacteria can be killed when heated at a regular cooking temperature, but the toxins remain active. In foodstuffs, staphylococcal enterotoxins are extremely heat tolerant and are known to be more heat resistant than in a laboratory culture medium. Staphylococcal food toxicity is due to the absorption in the food of staphylococcal enterotoxins.

\section{Introduction}

Staphylococcus aureus is a commensal and significant opportunistic pathogen that causes a wide range of diseases in humans and animals, with a high effect on public health and the livestock sector (Rahimi et al., 2015). $S$. aureus develops a large variety of staphylococcal enterotoxins with demonstrated emetic activities (SEs, SEA to SEE, SEG to SEI, SER to SET) as well as staphylococcal-like (SEL) proteins not emetic in the primate model (SElL and SElQ) (Argudin et al., 2010). Staphylococcal enterotoxins (SE) can cause toxin-mediated disease, and those that function as superantigens are implicated in the pathogenesis of allergic diseases (Varshney et al., 2009).

An estimated $0.1 \mu \mathrm{g}$ of SEs can cause staphylococcal food poisoning in humans (le Loir et al., 2003). S. aureus has been isolated from the nasal cavities of livestock animals 
and hence may be one of the important sources of contamination which may lead to staphylococcal food poisoning (Mourabit et al., 2020).

\section{Materials and Methods}

A total of 160 nasal swab samples of cattle were collected from different places of Aizawl, Mizoram, India.

All the swabs were processed for isolation and identification of $S$. aureus (Ewing, 1986). All the isolates were assessed by polymerase chain reaction (PCR) assay for the presence species specific gene (nuc gene) (Brakstad et al., 1992).

Those isolates positive for nuc gene were further assessed by PCR assay for the presence of classical SE gene(s)(sea, seb, sec, sed) (Cremonesi et al., 2005; Johnson et al., 1991) All the isolates were subjected to antimicrobial sensitivity assay by disc diffusion method using 13 commonly used antimicrobial agents (Bauer et al., 1966).

\section{Results and Discussion}

A total of 13 out of $160(8.12 \%)$ samples from were found to be positive nuc gene which was used for PCR for identification of $S$. aureus (Reddy et al., 2015). All the 13 nuc gene positive isolates were screened for the presence of virulence genes (sec and sed). A total of 1 isolate $(6.66 \%)$ for sec and 2 isolates $(13.36 \%)$ for sed were found to be positive respectively.

From the nasal swabs of goat, $6(18.75 \%)$ isolates were positive for sec gene (Zhou et al., 2017). In the food surveillance of South west China, 145 (57.77\%) and 43 (17.28\%) isolates were positive for sed and sec genes (Liao et al., 2018). SEC are located in chromosome (Klotz et al., 2003) and commonly isolated from animals (Pinchuk et $a l ., 2010)$. There are three subtypes of the sec gene (secl, sec2, and sec3) which are categorised into antigenic properties or diversity in enterotoxin $\mathrm{C}$ sequencing (Mousa et al., 2017) and this may be the reason for less detection of sec gene in our study.

Table.1 Antibiogram of sec and sed isolates detected from cattle nares in Aizawl, Mizoram

\begin{tabular}{|c|c|c|c|c|c|}
\hline \multirow{2}{*}{ Sl. no } & \multirow{2}{*}{ Antimicrobial agents } & \multicolumn{2}{|c|}{ sec (n=1) } & \multicolumn{2}{c|}{ sed (n=2) } \\
\cline { 3 - 6 } & & Resistance (\%) & Sensitive (\%) & Resistance (\%) & Sensitive (\%) \\
\hline $\mathbf{1}$ & Oxacillin (OC) & $100 \%$ & - & $100 \%$ & - \\
\hline $\mathbf{2}$ & Ampicillin (AMP) & $100 \%$ & - & $100 \%$ & - \\
\hline $\mathbf{3}$ & Cefoxitin (CX) & $100 \%$ & - & $100 \%$ & - \\
\hline $\mathbf{4}$ & Chloramphenicol (C) & $100 \%$ & - & $100 \%$ & \\
\hline $\mathbf{5}$ & Gentamicin (GEN) & - & $100 \%$ & - & $100 \%$ \\
\hline $\mathbf{6}$ & Ciprofloxacin (CIP) & - & $100 \%$ & - & $100 \%$ \\
\hline $\mathbf{7}$ & Tetracycline (TE) & $100 \%$ & - & $100 \%$ & - \\
\hline $\mathbf{8}$ & Erythromycin (E) & $100 \%$ & - & $100 \%$ & - \\
\hline $\mathbf{9}$ & Ceftriazone (CTX) & - & $100 \%$ & - & $100 \%$ \\
\hline $\mathbf{1 0}$ & Amikacin (AK) & - & $100 \%$ & - & $100 \%$ \\
\hline $\mathbf{1 1}$ & Kanamycin (K) & - & $100 \%$ & - & $100 \%$ \\
\hline $\mathbf{1 2}$ & Amoxyclav (AMC) & - & $100 \%$ & - & $100 \%$ \\
\hline $\mathbf{1 3}$ & Azithromycin (AZM) & $100 \%$ & - & $100 \%$ & - \\
\hline
\end{tabular}


Staphylococcal enterotoxins D on the other hand are carried by plasmid (Klotz et al., 2003) and they are frequently detected in $S$. aureus strains associated with intoxications (Shito et al., 2015). It is the second most enterotoxins associated with staphylococcal food poisoning (SFD) after SEA which was in accordance with other workers (Fisher et al., 2018; Argudin et al., 2010). To the best of our knowledge this may be the first report on detection of sec and sed genes from cattle nares in India. All the sec and sed genes isolates showed (Table 1) $100 \%$ resistance to ampicillin, tetracycline, erythromycin and azithromycin whereas gentamicin, ciprofloxacin, kanamycin and amoxyclav showed $100 \%$ sensitivity. Multiple drug resistance in the isolates may be due to acquired antibiotic resistance such as resistance by mutation, acquisition of resistance genes or it may be due to intrinsic factors like outer membrane permeability, efflux systems etc (Guo et al., 2020). In Mizoram, cattles are regarded as the main source of milk, milk products and meat products and the appearance of $S$. aureus isolates with multi-drug resistance may suggests that they can serve as a significant reservoir that presents a potential public health concern and can complicate possible therapeutic options.

\section{Acknowledgement}

The authors are thankful to Dean, College of Veterinary Science and Animal Husbandry, Central Agricultural University, Selesih, Aizawl, Mizoram, India for providing necessary funds and facilities to carry out the investigation.

\section{References}

Argudin, M.A., Mendoza, M.C. and Rodicio, M.R. 2010. Food poisoning and Staphylococcus aureus enterotoxins.
Toxins (Basel)., 2(7): 1751-1773.

Bauer, A.W., Kirby, W.M., Sherriz, J.C. and Tuck, N. 1966. Antibiotic susceptibility testing by standardized single disc method. Am. J. Clin. Pathol., 45: 493-496.

Brakstad, O.G., Aasbakk, K. and Maeland, J.A. 1992. Detection of Staphylococcus aureus by polymerase chain reaction amplification of the nuc gene. J. Clin. Microbiol., 30(7): 1654-1660.

Cremonesi, P., Luzzana, M., Brasca, M., Morandi, S., Lodi, R., Vimercati, C., and Castiglioni, B. 2005. Development of a multiplex PCR assay for the identification of Staphylococcus aureus enterotoxigenic strains isolated from milk and dairy products. Mol. Cell. Probes., 19(5): 299-305.

Ewing, W. H. (1986). The genus Escherichia,p. 93-122. In P. R. Edwards and W. H Ewing (ed), Edwards and Ewing's identification of Enterobacteriaceae, $4^{\text {th }}$ ed. Elsevier Science Publishing Co Inc., New York, N. Y.

Fisher, E.L., Otto, M. and Cheung, G.Y.C. 2018. Basis of virulence in enterotoxin-mediated staphylococcal food poisoning. Front. Microbiol., 9: 436.

Guo, Y., Song, G., Sun, M., Wang, J. and Wang, Y. 2020. Prevalence and Therapies of Antibiotic-Resistance in Staphylococcus aureus. Front. Cell. Inf. Microbiol., 10: 107.

Johnson, W. M., Tyler, S. D., Ewan, E. P., Ashton, F. E., Pollard, D. R., and Rozee, K. R. 1991. Detection of genes for enterotoxins, exfoliative toxins, and toxic shock syndrome toxin 1 in Staphylococcus aureus by the polymerase chain reaction. J. Clin. Microbiol., 29(3): 426-430.

Klotz, M., Opper, S., Heeg, K. and Zimmermann, S. 2003. Detection of 
Staphylococcus aureus enterotoxins A to D by real-time fluorescence PCR assay. J.clin. microbiol., 41(10): 46834687.

le Loir, Y., Baron, F. and Gautier, M. 2003. Staphylococcus aureus and food poisoning. Genet. Mol. Res., 2(1): 6376.

Liao, F., Gu, W., Yang, Z., Mo, Z., Fan, L., Guo, Y., Fu, X., Xu, W., Li, C., and Dai, J. (2018). Molecular characteristics of Staphylococcus aureus isolates from food surveillance in southwest China. BMC Microbiol., 18: 91 https://doi.org/10.1186/s12866018-1239-Z

Mourabit, N., Arakrak, A., Bakkali, M., Zian, Z., Bakkach, J. and Laglaoui, A. 2020. Nasal carriage of Staphylococcus aureus in farm animals and breeders in North of Morocco. BMC Infect. Dis., 20: 602. doi: 10.1186/s12879-02005329-4

Mousa, W.S., Abdeen, E., Hussein, H., Hadad, G. 2017. Prevalence and multiplex PCR for enterotoxin genes of Staphylococcus aureus isolates from subclinical mastitis and kareish cheese. J. Infect. Dis. Preven. Med., 5(174): 2.
Pinchuk, I.V., Beswick, E.J. and Reyes, V.E. 2010.

Staphylococcal enterotoxins. Toxins., 2(8): 2177-2197.

Rahimi, H., Saei, H. D. and Ahmadi, M. 2015. Nasal carriage of Staphylococcus aureus: Frequency and antibiotic resistance in healthy ruminants. Jundishapur Microbiol., 8(10):e22413 2

Reddy, M.S., Babu, A.J., Ramya, P. and Swetha, C.S. 2015. Molecular characterization of methicillin resistant Staphylococcus aureus from goats, pigs and their handlers. Int. $J$. Microbiol. Res., 7(3): 648-655.

Varshney, A. K., Mediavilla, J. R., Robiou, N., Guh, A., Wang, X., Gialanella, P., and Fries, B.C. 2009. Diverse enterotoxin gene profiles among clonal complexes of Staphylococcus aureus isolates from the Bronx, New York. Appl. Environ. Microbiol., 75(21): 6839-6849.

Zhou, Z., Zhang, M., Li, H., Yang, H., Li, X., Song, X.and Wang, Z. 2017. Prevalence and molecular characterization of Staphylococcus aureus isolated from goats in Chongqing, China. BMC Vet. Res., 13(1): 352.

\section{How to cite this article:}

Lalnunfela, J. Lalmuanpuia, E. Motina, D. Deka and Lallawmkimi, G. J. 2021. Molecular Detection of Staphylococcal enterotoxin C (SEC) and Staphylococcal enterotoxin D (SED) from the Cattle Nares in Aizawl, Mizoram (India). Int.J.Curr.Microbiol.App.Sci. 10(02): 12501253. doi: https://doi.org/10.20546/ijcmas.2021.1002.147 